\title{
An experimental study of the performance and emissions of spark ignition gasoline engine
}

\author{
Adnan Kadhim Rashid", Mohd Radzi Abu Mansor,,2,*, Wan Aizon Wan Ghopa ${ }^{1,2}$, \\ Zambri Harun ${ }^{1,2}$, Wan Mohd Faizal Wan Mahmood ${ }^{1,2}$ \\ ${ }^{1}$ Department of Mechanical \& Materials Engineering \\ Faculty of Engineering \& Built Environment \\ 43600 UKM Bangi, Selangor, Malaysia \\ ${ }^{2}$ Centre for Automotive Research, Faculty of Engineering \& Built Environment \\ 43600 UKM Bangi, Selangor, Malaysia \\ *Email: radzi@ukm.edu.my
}

\begin{abstract}
The resistance of gasoline to knocking is critically determined by the octane number. The engine will encounter a significant waste of power, reduced efficiency and enhanced emission levels if a well-defined gasoline octane number is not employed. In this study, the engine performance and emission of hazardous gases were experimentally investigated through the use of three gasoline fuels (RON95, 97 and 102). The engine selected for the testing was a 1.6-L four-cylinder Toyota 4A-GE Blacktop VVT with the original ECU. The engine was run at different constants for various part load conditions as well as at constant throttle body. The engine that was operated with RON97 fuel was found to display positive improvements in terms of the brake specific fuel consumption of the engine, reduced at an average of 5 and 10\%, compared to RON102 and RON95 fuels, respectively. Furthermore, the engine operated with RON102 fuel exhibited higher torque and engine power compared to RON97 and RON95. The brake thermal efficiency for both RON97 and RON102 fuels was remarkably improved at an average of 12\% compared to RON95. The incorporation of RON102 fuel reduced the emission of $\mathrm{NO}_{\mathrm{X}}$ compared to RON95 and RON97 fuels at an average of $34 \%$ and $40 \%$, respectively. The RON102 fuel produced the highest HC emission compared to RON97 and RON95. The CO emission was found to be higher for RON102 fuel compared to RON97 and RON95 at an average of $12.4 \%$ and $17 \%$, respectively. The study concluded that although engine performance and efficiency versus gasoline depend highly on the engine design parameters, RON97 is able to deliver high performance and efficiency in all conditions. Therefore, it is recommended that RON97 be used instead of RON95 to achieve better performance with this type of engine.
\end{abstract}

Keywords: RON, engine performance; emission; constant throttle body; VVT; energy efficient vehicle.

\section{INTRODUCTION}

The clean energy crisis and environmental risks are the main challenges to the [1] efficient vehicles are the main focus of the Malaysian National Automotive Policy (NAP) and car industry [2]. The primary aims of using spark ignition (SI) engine fuels are to improve the fuel characteristics in terms of reduced consumption of engine fuel, enhanced engine power and minimised redundant emissions [3, 4]. Over the years, significant 
advancements have been made in SI engines [5-7]. SI engines have been adapted for three-way catalysts with advanced engine designs and improved fuel properties. Lately, researchers [8-11] have been focusing more on the octane number. This is because the exhaust emissions from automobiles and the subsequent engine performance are known to be determined by the gasoline quality, which depends on the octane number. In view of this, the engine performance and exhaust emissions for gasoline-powered SI engines were examined in this study. An engine may be running smoothly when it is in operation, but pressure may develop suddenly on the piston. The air-fuel mixture will be ignited during the compression period but, before it is ignited by the flame, small explosions will be created during the combustion, thereby causing knocking [12-14]. This can be avoided by using a higher RON fuel, as revealed by reports on the thermodynamic performance and combustion of SI engines [15]. Extensive research is being carried out into the octane number of gasoline fuels as one of the most important parameters for determining the effect of fuel quality on detonation resistance [16-18]. The impact of higher-octane gasoline on engine performance is also being scrutinised.

Sayin, Kilicaslan [8] studied the effect of higher-octane gasoline usage in terms of fuel economy and exhaust emissions. RON91 and RON95 gasoline fuels were tested, followed by the engine requirements. They also investigated and predicted the BSFC, BTE, exhaust gas temperature, and exhaust emissions of the engine [19]. It was established that the RON and MON numbers are strongly correlated to the engine performance. These are the most important parameters for characterising the auto ignition of gasoline in engines [20]. The effect of varying the spark timing for different gasoline octane numbers on engine emission and performance has been studied. The results showed a decrease in the BTE and an increase in the BSFC owing to the use of a higher RON fuel than that which is required by the engine. However, a change in the spark timing from $23^{\circ} \mathrm{CA} \mathrm{BTDC}$ to $26^{\circ} \mathrm{CA}$ BTDC caused an increase in the BTE, a reduction in BSFC and unwanted exhaust emissions [9]. Figure 1 illustrates the engine speed (from 1000 to $3000 \mathrm{rpm}$ ) versus variations of the BTE for gasoline with different octane ratings, namely RON91, 93, 95, 97 and 98. The highest BTE was observed to be 37\%, which was achieved at an engine speed of $2500 \mathrm{rpm}$ and $23^{\circ} \mathrm{CA}$ BTDC for RON95. Figure 2 displays the variation of BTE as a function of spark timing (20,23 and $26^{\circ} \mathrm{CA}$ BTDC) with different gasoline octane numbers of RON91, 93, 95, 97 and 98. The highest BTE was found to be $38.1 \%$. This was achieved at $2500 \mathrm{rpm}$ and $26^{\circ} \mathrm{CA}$ BTDC for RON98 gasoline. This enhancement in BTE tended to reduce knocking and fuel consumption $(221 \mathrm{~g} / \mathrm{kWh})$. However, knocking was increased with an increase in the spark timing for RON91, 93 and 95 gasoline [9].

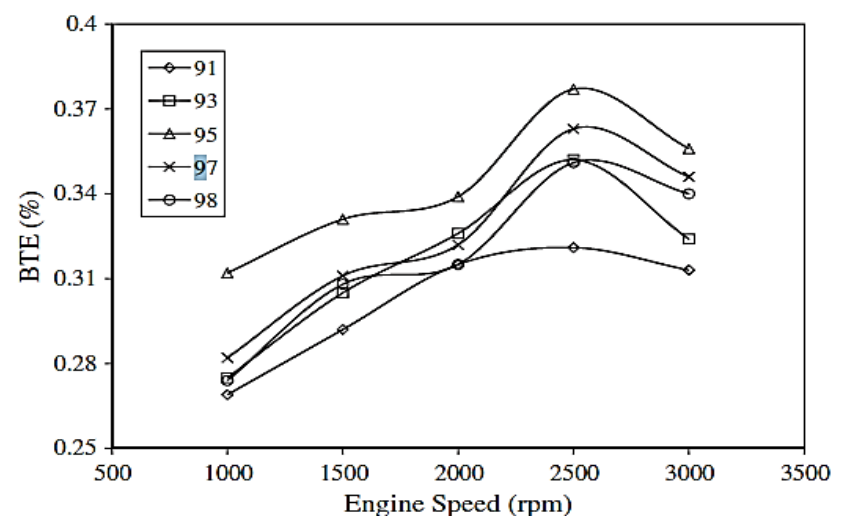

Figure 1. Engine speed versus the BTE (\%) [9]. 


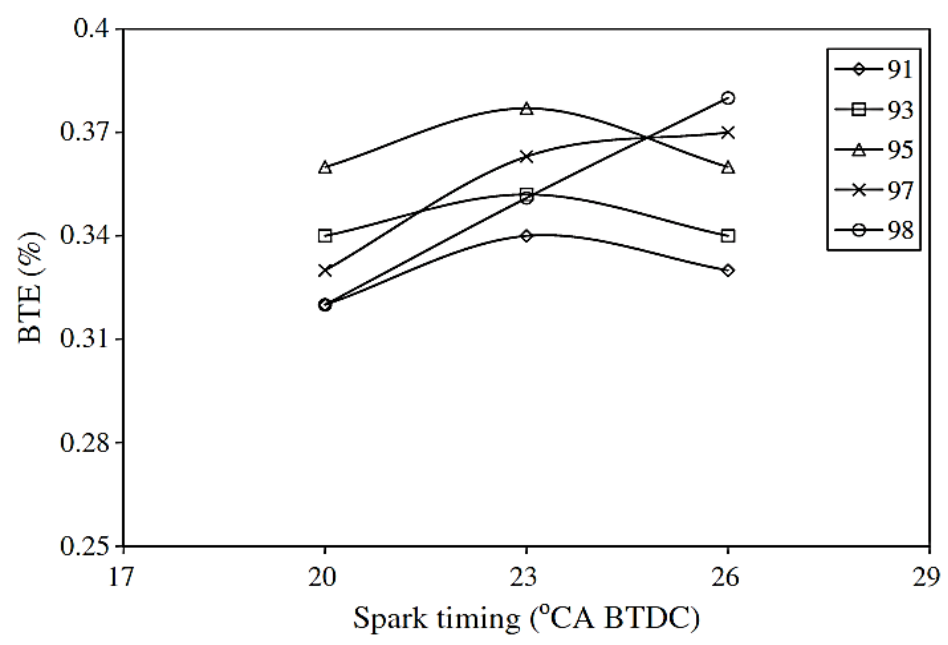

Figure 2. Spark timing versus the BTE (\%) [9].

In a study by Mohamad and How [10] conducted on a 1.6-L, four-cylinder Mitsubishi 4G92 engine with CR 11:1, the engine was run at a constant speed of between 1500 and $3500 \mathrm{rpm}$ with an increment of $500 \mathrm{rpm}$ under various part load conditions. RON95 produced a higher engine performance for all part load conditions within the speed range. An average $4.4 \%$ increase in brake torque, brake power and brake mean effective pressure was achieved compared to RON97. In terms of exhaust emissions, RON95 produced $7.7 \%$ lower $\mathrm{NO}_{x}$ emissions, but higher $\mathrm{CO}_{2}(7.9 \%), \mathrm{CO}(36.9 \%)$ and HC $(20.3 \%)$ emissions. However, RON97 was found to be advantageous with a lower BSFC of $2.3 \%$ for all load conditions. Several researchers determined the effect of the variation of fuel properties based on the octane number on engine performance, fuel consumption and emissions. Fuels such as ethanol, methanol and butanol not only possess high octane ratings but also have greater heats of evaporation. These make them suitable fuels for high CR engines with elevated powers [20]. High octane values allow a significant increase in the compression ratio. Conversely, the high heat of evaporation cools down the incoming fuel-air charge and makes it denser so as to achieve a superior power output. Fuels with high auto ignition temperatures are usually ignited at higher temperatures. It has been revealed that methanol has a lower tendency for knocking and lower emissions than gasoline [21]. The use of a mixture of methanol and gasoline in SI engines was demonstrated by [22]. They studied the methanol-gasoline blend without any retrofitting of the engine. It was found that there was a reduction in the engine power and torque when the methanol fraction in the fuel blend was increased under wide open throttle conditions [23]. Other alternative fuels have been compared and their effects on the performance and emission characteristics of engines have been reported. It is acknowledged that hydrogen has the lowest volumetric efficiency in engines. Conversely, gasoline generates more power than all other tested alternative fuels. Besides, the BSFC of methanol (91\%) is higher than that of gasoline, while the BSFC of hydrogen (63\%) is less than that of gasoline. Several experimental studies have been performed to achieve the perfect blend of ethanol and gasoline with a high compression ratio [21]. Ethanol is used as fuel at a high compression ratio to improve the performance and to reduce emissions in small gasoline engines with low efficiency. Recently, Merola, Valentino [24] used a blend of $20 \%$ volume of n-butane with commercial gasoline to determine the knocking combustion of an SI engine. Knop, Loos [25] considered a ternary mixture of n-heptane, toluene and isooctane to evaluate a linear-by-mole blending rule. Babu, Rao 
[26] determined the effect on the emission and performance of a gasoline engine of injecting a water mist into an intake manifold through a nozzle at the throttle body. It was found that the performance and volumetric efficiency of the engine were increased by up to $10 \%$.

A further study was carried out by [27] on variations in the load and engine speed by using a single-cylinder spark four-stroke gasoline engine coupled to a dynamometer. The standard air intake system resulted in a rich combustion process, while incomplete combustion reduced the air intake. Therefore, for better combustion it is necessary to increase the air intake pressure so as to produce higher engine efficiency. The present paper experimentally investigated the possibility of increasing the engine performance while simultaneously reducing the emission of hazardous gases and optimising the combustion parameters of SI engines through the use of a suitable RON fuel to ensure the emission of less pollutant gases and improved efficiency through the use of three gasoline fuels (RON95, 97 and 102).

\section{METHODS AND MATERIALS}

\section{Experimental Design}

This study plays a significant role in the development of the energy sector. The continuous depletion of fossil fuel energy sources and the problems encountered with engines due to the use of poor quality fuels have led to a search for proper alternatives. Blending a fuel with different RON fuel types is expected to provide the engine with a longer life and maximum energy output, but the fuel consumption will be higher. The economy is more likely to be outweighed by all the savings made at the fuel pump. For the octane number specifications, one of the effective ways is the use of octane number improvers. For this reason, an experiment was carried out to study the combustion characteristics of various octane ratings for the feasibility of energy efficient vehicles. The engine performance and exhaust emissions using RON95, RON97, and RON102 grade fuels were experimentally analysed using a Toyota 4A-GE VVT engine. A schematic diagram of the experimental setup is shown in Figure 3.

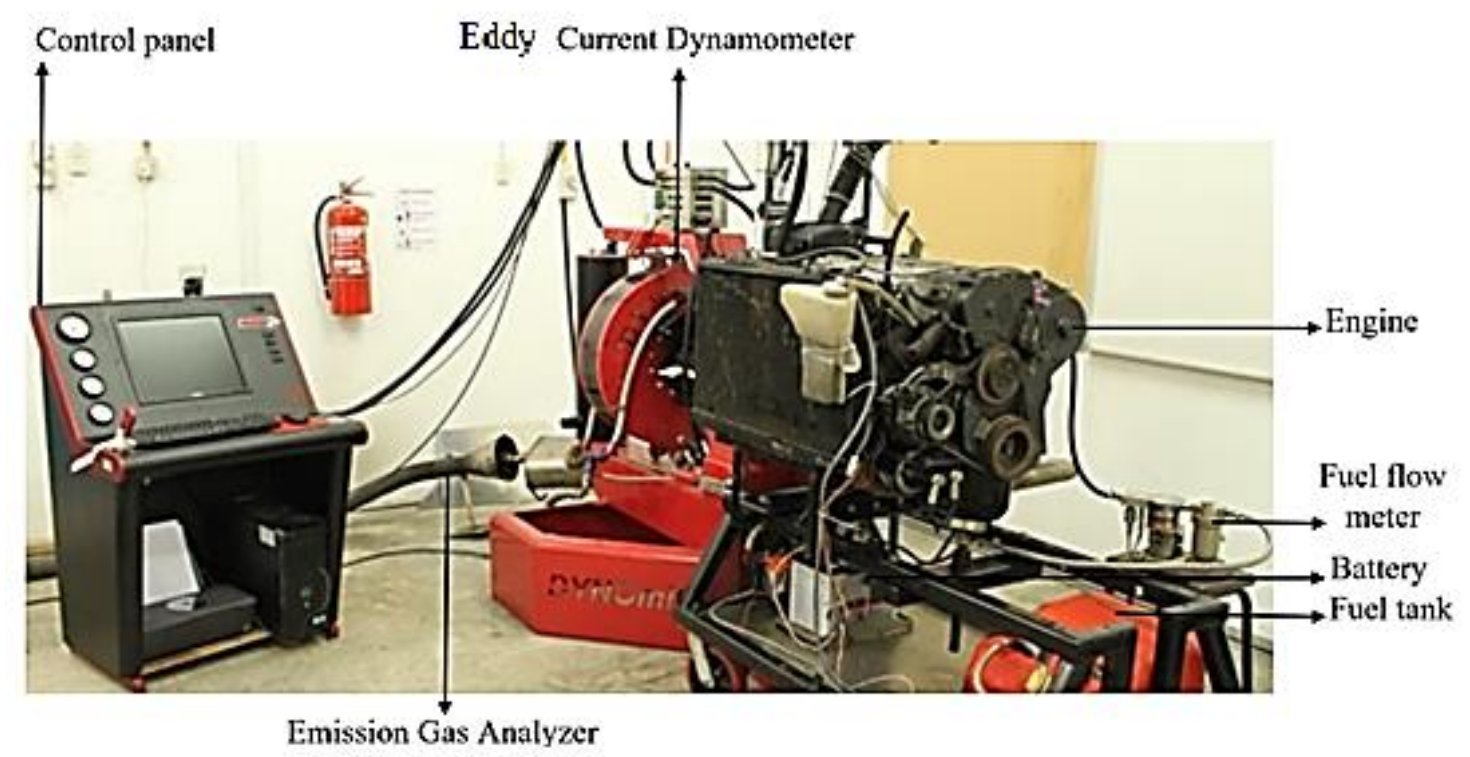

Figure 3. Schematic diagram of the experimental setup. 
Figure 4 shows the general steps that were used in the current study, which included two loops for the change in the delivery of the applied load and the change in the kind of RON fuel for the operation to examine the possibility of increasing the engine performance to simultaneously reduce the emission of hazardous gases with the use of three types of gasoline fuels (RON95, 97, and 102). Note that the experiments included 18 stages of different parameters.

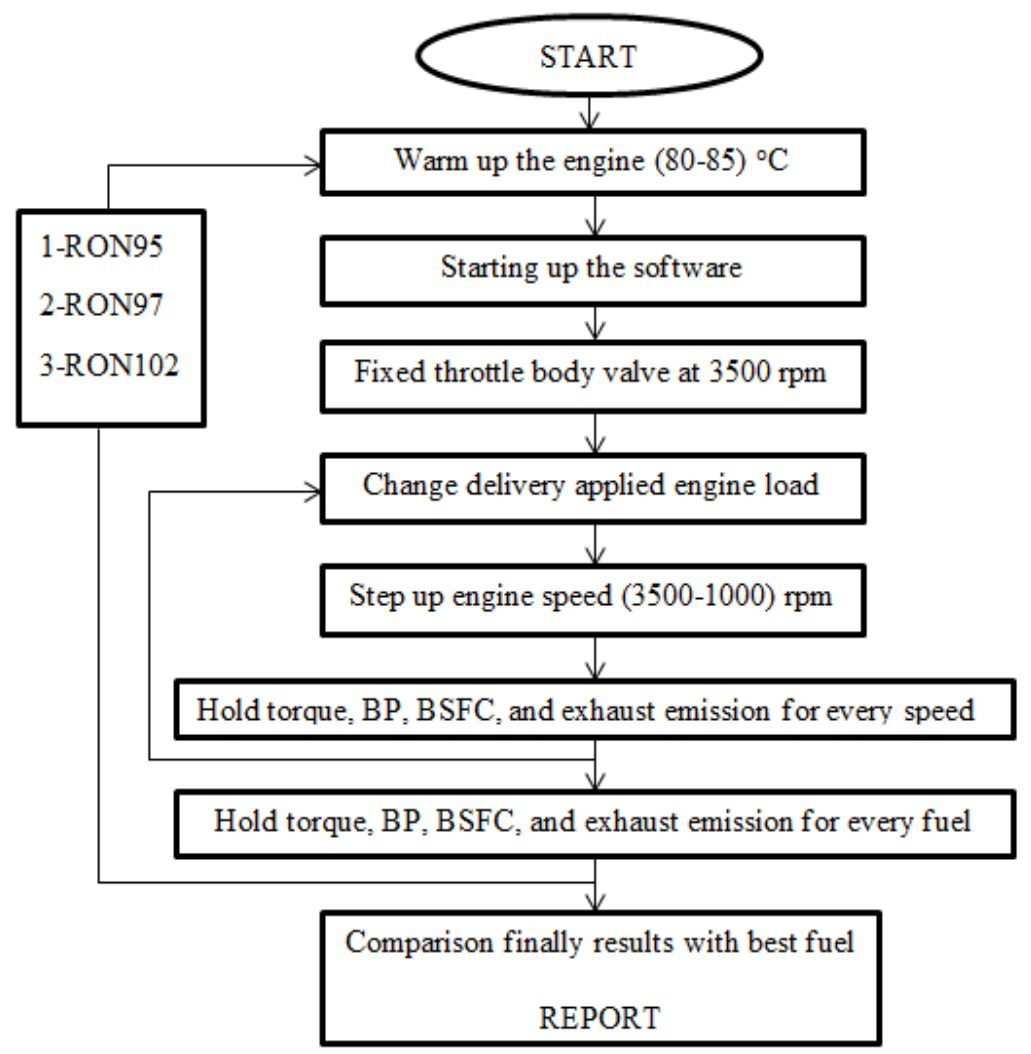

Figure 4. Experimental process.

\section{Experimental Procedure}

A 1.6-litre, four-cylinder Toyota 4A-GE Blacktop engine with a compression ratio of 11:1 was used, as specified in Table 1. The schematic diagram of the experimental set-up is shown in Figure 3. An eddy current dynamometer with a load capacity of $150 \mathrm{~kW}$ and a maximum possible velocity of $8000 \mathrm{rpm}$ was used to absorb the power produced by the engine with the capability of applying a brake load to the engine shaft. DYNO-MAX 2010 software, which is an NT-based system, was used for the testing, where the information and data were transferred from all the engine parts to the control panel. The DYNO-MAX 2010 software was attached to the dynamometer as well as the engine for alterations in loading and speed. It provided information regarding engine factors such as the air and gas temperature, power, torque, engine lubrication and furnace water temperature. The gasoline consumption was measured using a fuel flow meter (Ono Sokki). An emission gas analyser (EMS) was used to measure the exhaust emissions of $\mathrm{CO}_{2}, \mathrm{CO}, \mathrm{HC}$ and $\mathrm{NO}_{\mathrm{x}}$. The probe of the gas analyser (HHGA-8) was placed 1 metre downstream of the exhaust manifold from the exhaust valves. An oxygen sensor was placed in the exhaust manifold to monitor the equivalence ratio of the cylinder charge. The engine was operated at a 
constant throttle body of $18 \%$ at a constant speed ranging from 3500 to $1000 \mathrm{rpm}$ in steps of $500 \mathrm{rpm}$ with a gradual reduction by an increase in the applied load from the dynamometer on the engine. All the data were recorded after the engine oil had reached a stable temperature range of between 80 to $90{ }^{\circ} \mathrm{C}$. Some of the measured thermal and physical properties of the gasoline used in the present experiment are summarised in Table 2.

Table 1. Specifications of the Toyota 4A-GE engine.

\begin{tabular}{lc}
\hline \multicolumn{1}{c}{ Engine model } & Toyota 4A-GE \\
\hline Valve train & DOHC VVT (Variable Valve Timing ) \\
Number of cylinders & 4 \\
Total volume displacement & $1587 \mathrm{cc}$ \\
Compression ratio & $11: 1$ \\
Number of intake valves & 12 \\
Number of exhaust valves & 8 \\
Maximum rated power & $123 \mathrm{~kW} / 7800 \mathrm{rpm}$ \\
Maximum rated torque & $163 \mathrm{Nm} / 5200 \mathrm{rpm}$ \\
\hline
\end{tabular}

Table 2. Properties of fuels.

\begin{tabular}{lcccc}
\hline $\begin{array}{l}\text { Fuel } \\
\text { Type }\end{array}$ & Colour & $\begin{array}{c}\text { Average Density } \\
\left(\mathrm{g} / \mathrm{cm}^{3}\right)\end{array}$ & $\begin{array}{c}\text { Reid Vapour } \\
\text { Pressure }(\mathrm{kPa})\end{array}$ & $\begin{array}{c}\text { Calorific Value } \\
(\mathrm{MJ} / \mathrm{kg})\end{array}$ \\
\hline RON95 & Yellow & 0.751 & 60.03 & 43304 \\
RON97 & Red & 0.760 & 60.03 & 43961 \\
RON102 & Light & 0.710 & 71.90 & 44040 \\
& straw & & & \\
\hline
\end{tabular}

\section{RESULTS AND DISCUSSION}

The engine performance in response to RON95, RON97 and RON102 gasoline was inspected at a constant throttle body (18\%) with various engine speeds. The values of the torque, brake power, BTE, BSFC and exhaust emissions were determined. The results were derived directly from the measured experimental data and were calculated using Heywood's equation [28]. Figure 5 presents the engine speed versus changes in the torque. The variation of brake power as a function of engine speed is displayed in Figure 6 . The average torque of the engine fuelled with RON102 increased by $13 \%$ and $6 \%$ compared to the RON95 and RON97 fuels, respectively. Moreover, the brake power produced using RON102 achieved the highest output, followed by RON97 and RON95. The results contrasted with the findings of [6], who obtained higher performance from RON95 compared to the other higher RON fuels. The higher performance observed for the engine operated on RON95 was attributed to the original engine construction, which had been optimised for a lower fuel octane rating with a relatively low compression ratio. Studies by Sayin [9] showed that the advantage of using a higher RON fuel cannot be realised to its maximum without making some engine modifications and it was shown that the use of a higher RON fuel than that recommended for the engine design will lead to a reduction in the engine torque but, on the other hand, with the increased spark timing to $26^{\circ} \mathrm{CA} \mathrm{BTDC}$, the engine performance will be higher and the BSFC will be lower. 
Sayin [9], [10] investigated the effect of various octane numbers on the performance of engines. It was found that a higher octane number does affect the performance of engines. However, the engine performance is highly dependent on the design of the engine, especially when a specific engine is designed for low RON fuel. Mohamad and How [10] confirmed the result of [9]. By using RON95 and RON97, they found that RON95 produced a higher torque than RON97 owing to the fact that if the engine was optimised for the lower fuel octane rating with a low compression ratio, then using a fuel with a higher octane rating for this type of engine may not result in better performance. In the current study, it was shown that the use of the VVT feature can advance or retard the angle of the intake valves, which helps to provide the maximum amount of air to change the speed of the engine. So, the advancement of the spark timing engine to produce enhanced engine performance through the use of a higher RON fuel is worth looking into.

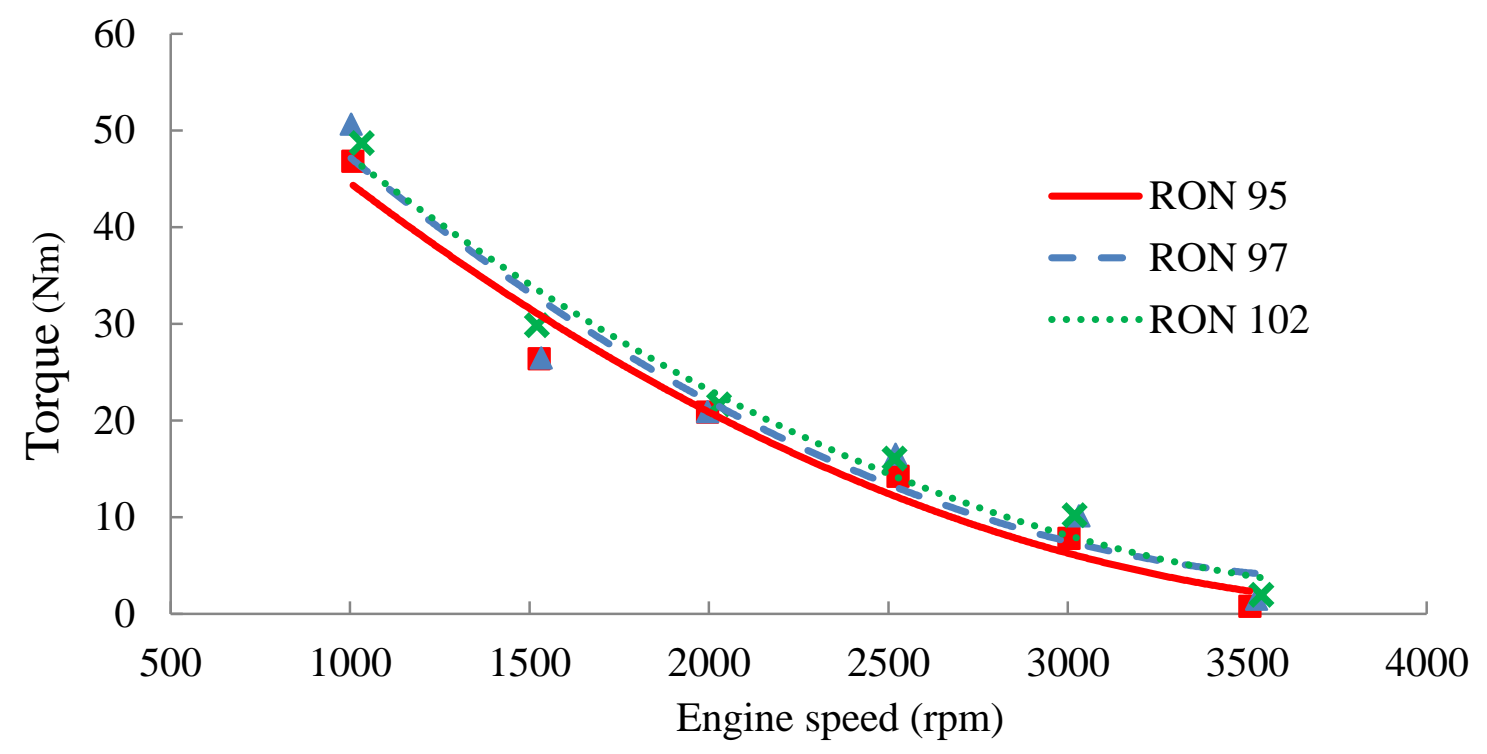

Figure 5. Variation of torque against engine speed.

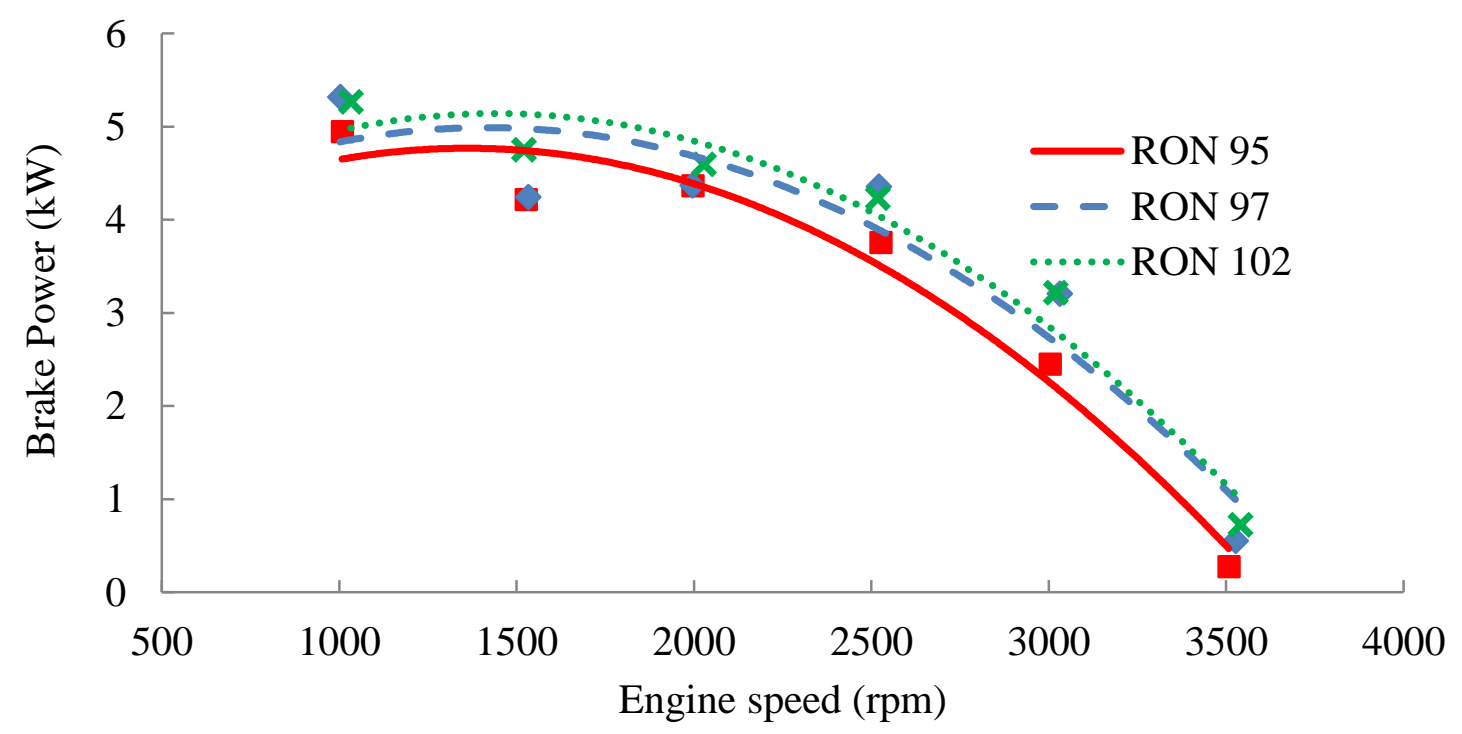

Figure 6. Effect of brake power with engine speed. 
Figure 7 depicts the dependence of thermal efficiency on the engine speed at a constant throttle body of $18 \%$. It was observed that the BTE increased with decreasing engine speed via the applied engine load. Both the RON97 and RON102 fuels indicated no significance difference in their thermal efficiency compared to the RON95 fuel, and produced an average of $12 \%$ in thermal efficiency. This was an encouraging improvement in engine conditions through the use of a higher RON. Furthermore, it was found that the BTE was low at high speeds. The highest efficiency was achieved at $1000 \mathrm{rpm}$ (low speed) with a high load. This reflected the effect of a higher heating value for RON97 than RON95, while the lower heating value for RON102 was more than for RON97. The BTE for RON97 was found to be higher than for RON102. This was because a longer combustion duration was required with a higher heating value. A decrease in temperature for RON102 was accompanied by a decrease in compression because of the shorter duration for fuel combustion [10]. Sayin [9] showed that at a speed of $2500 \mathrm{rpm}$ RON95 produced the highest BTE. With the increased spark timing $\left(26^{\circ} \mathrm{CA}\right.$ BTDC) production of higher BTE using a higher octane rating, there was a remarkable reduction in engine knocking, and it was claimed that the BTE was higher for the higher octane rating than for RON95, and knocking was observed to be lower for RON91, 93 and 95 gasoline fuels with increasing spark timing of the engine.

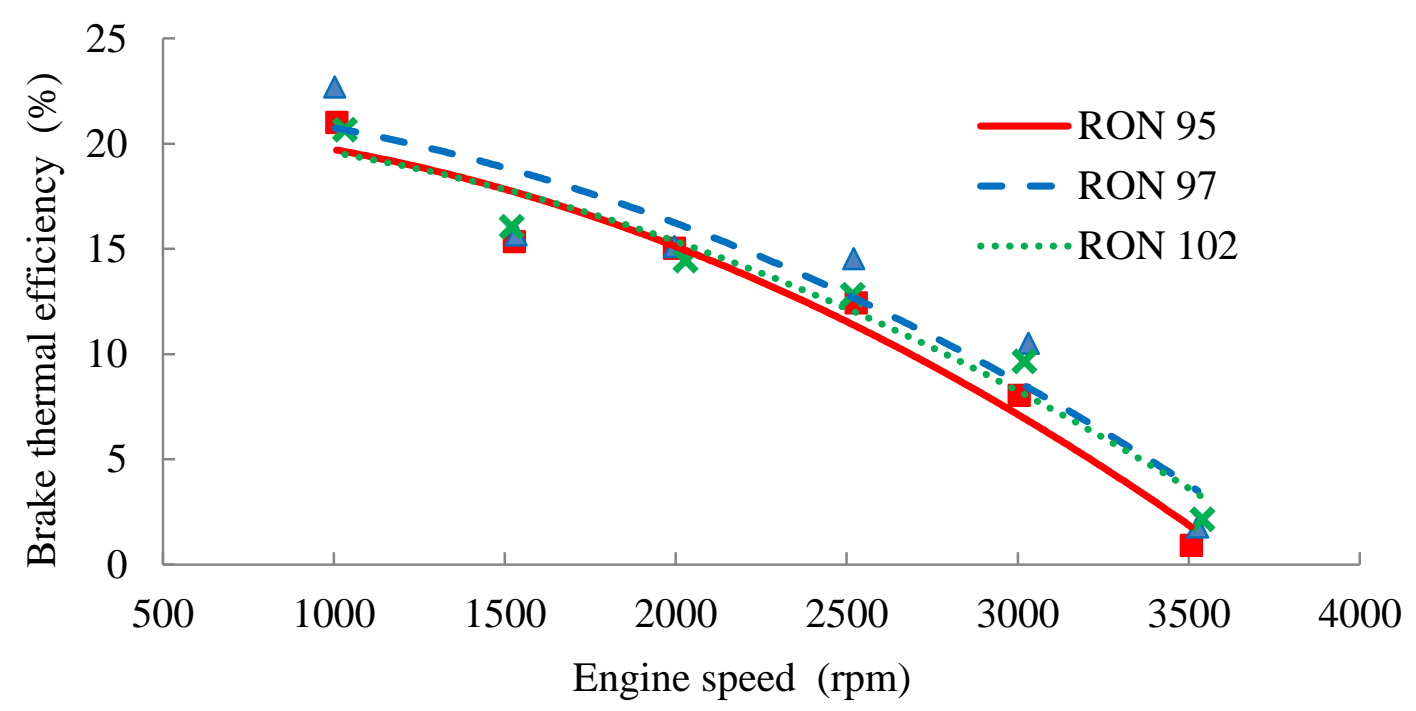

Figure 7. Variation of brake thermal efficiency against engine speed.

Figure 8 shows that predictable trends were observed in the BSFC behaviour of all three fuels. It was found that the fuel consumption was reduced with an increase in the load and the speed decreased with a constant throttle body of $18 \%$. The engine that was operated on RON97 fuel showed the lowest BSFC of $365 \mathrm{~g} / \mathrm{kWh}$ compared with RON95 and RON102 fuels (average of 10\% and 5\%, respectively). This decrease in the value of the BSFC considerably reduced the fuel consumption. This clearly showed that there was an improvement in the engine efficiency in terms of the fuel consumption and the rate of emissions. The agreement in behaviour of these three fuels with respect to the BTE and BSFC are explained as follows: RON95 has less resistance to auto ignition compared to RON97 gasoline fuel. This effect increased the BSFC and caused the deterioration of combustion. A decrease in fuel consumption with increasing load and speed was observed. Furthermore, RON97 exhibited superior fuel consumption with a lower BSFC 
at higher engine load conditions. Overall, RON97 resulted in a 2.3\% lower BSFC than RON95. For 97\% isooctane, the calorific value is normally higher. Thus, the engine needed less fuel mass per unit power to be produced, resulting in a lower BSFC. The lower energy content enhanced the BSFC without the need to perform any modifications to the engine [29]. Sayin [9] stated that a higher octane rated gasoline has higher engine optimisation and design requirements. Thus, when a higher rated fuel is used, the ignition delay will be longer and the flame speed will be shorter. In the results, the maximum pressure and engine power output were reduced and the BSFC was increased. On the other hand, the study further mentioned that the lower rated RON91 gasoline became less resistant to auto ignition compared to RON95, and this effect increased the BSFC. However, after some modifications were made to the engine by increasing the spark timing to $26^{\circ} \mathrm{CA}$ BTDC instead of $23^{\circ} \mathrm{CA}$ BDTC, it was found that the higher RON produced less BSFC, and the finding of this study confirmed that the higher octane RON97 has a lower fuel consumption compared to RON95.

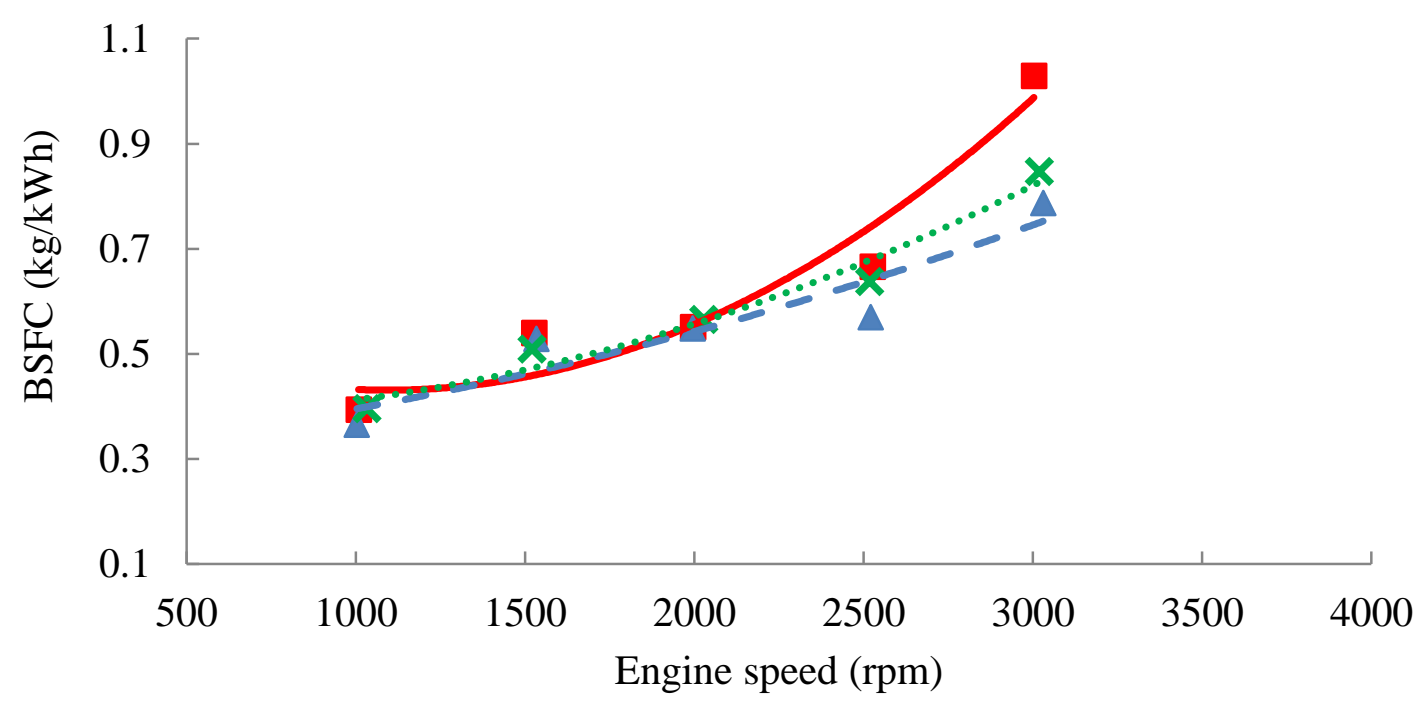

Figure 8. Variation of brake specific fuel consumption with engine speed.

The BSFC for RON102 was found to be higher than for RON97. It is important to note that RON102 possesses an excessive octane rating that is higher than the requirement of the engine that was being used. The ignition delay was found to be longer and the speed of the flame was lower. These caused a reduction in the maximum pressure and engine output power. The observed increase in fuel consumption per output power (in the absence of any engine modification) was in good agreement with the findings in [9]. The value of the VVT, which provided the volumetric efficiency to complete the combustion in the engine, was found to reduce the fuel consumption with increasing RON. This result contradicted the findings of $[8,9]$, but agreed well with the observation of Mohamad and How [10]. The design of the engine for a specific fuel is one of the important factors for reducing the BSFC value. In this case, it was obvious that the Toyota 4A-GE engine was VVT, which provided more volumetric efficiency to reduce fuel consumption by increasing the RON octane rating, and this contributed to the different results when compared to those of previous studies.

Figures 9 to 11 illustrate the measured exhaust emissions of $\mathrm{CO}, \mathrm{HC}$ and $\mathrm{NO}_{\mathrm{x}}$ from RON95, RON97 and RON102 operations in all test conditions. Figure 9 displays 
the engine speed versus variations in the $\mathrm{CO}$ emissions. It was observed that there was an increase in CO emissions with an increase in the engine speed until $2000 \mathrm{rpm}$. Then, the $\mathrm{CO}$ emissions were reduced to a minimum value at a high engine speed of $3500 \mathrm{rpm}$ and a light load. The $\mathrm{CO}$ emission distribution was convex in nature. In addition, the usage of RON102 fuel revealed an increase in CO emissions at an average of $12.4 \%$ and $17 \%$ compared to RON97 and RON95 fuels, respectively.

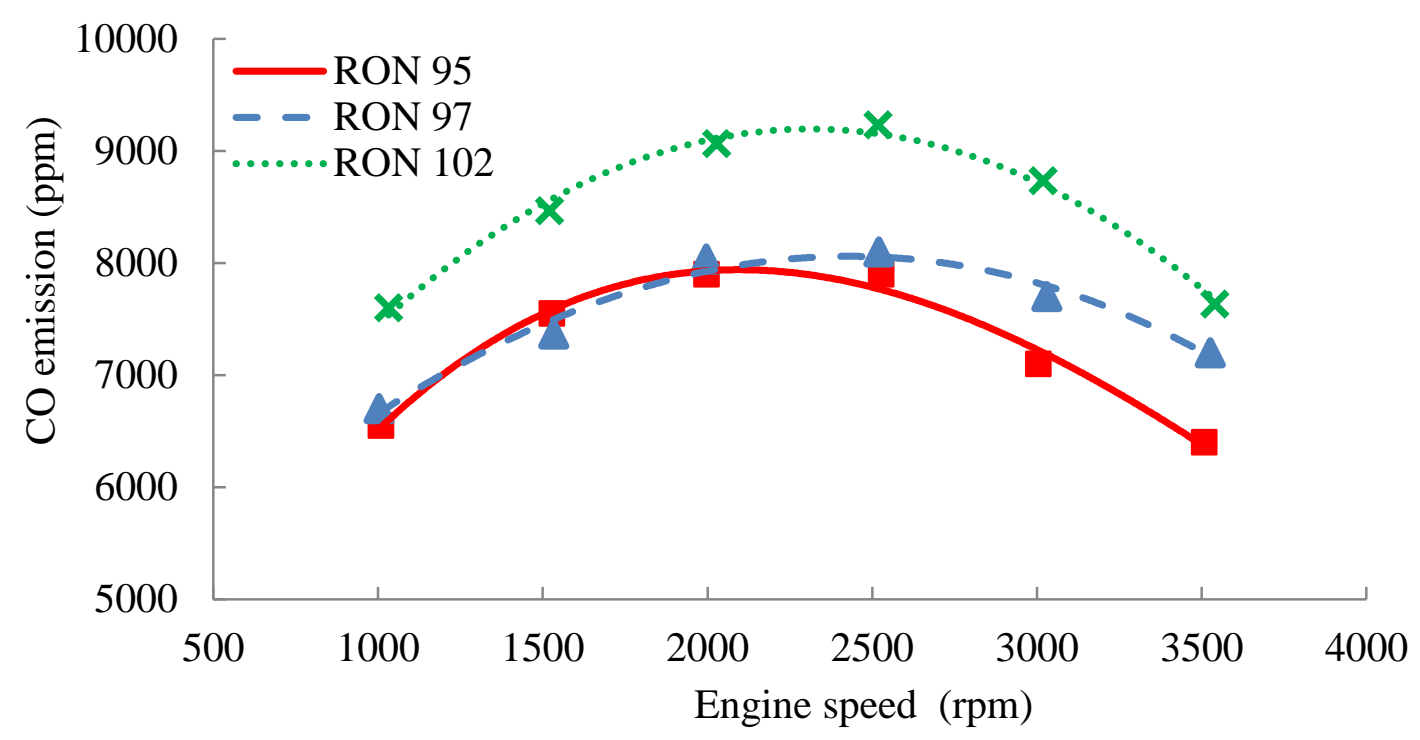

Figure 9. Variation of carbon monoxide emission with engine speed.

The $\mathrm{CO}$ emissions can be lessened by changing the engine speed and loads appropriately. The effect of a reduction in speed from 2000 to $1000 \mathrm{rpm}$ and an enhancement from 2000 to $3500 \mathrm{rpm}$ with reduced loads was a decrease in the CO emission. In short, the $\mathrm{CO}$ emissions for every operational condition were found to decrease with an increase in engine speed, indicating an improved combustion process. An increase in the load certainly enhanced the volumetric efficiency and boosted the turbulence in the combustion chamber. This ensured a more homogenous mixture and better combustion with safety and durability [29]. The observed enhanced $\mathrm{CO}$ emission with increasing engine speed altered the spark timing automatically by means of the combustion analyser and ECU engine. However, no automatic change in the spark timing was observed in the current experiment.

The use of RON95 slightly reduced the CO emissions compared to the other RON fuels. RON97 had higher power and torque coupled with higher heating than RON95, but it was noted here that there was a deviation in the CO emissions with RON97, which were higher than that of RON95. With regard to the fact that the emission of CO depends more on the engine design, [9] and [10], conducted an experiment to compare the $\mathrm{CO}$ emissions with RON97 to those of RON95, and discovered that the CO emissions from RON97 was higher despite the fact that RON95 generated more heat than RON97, proving that the lower octane fuel generated more power and torque. 


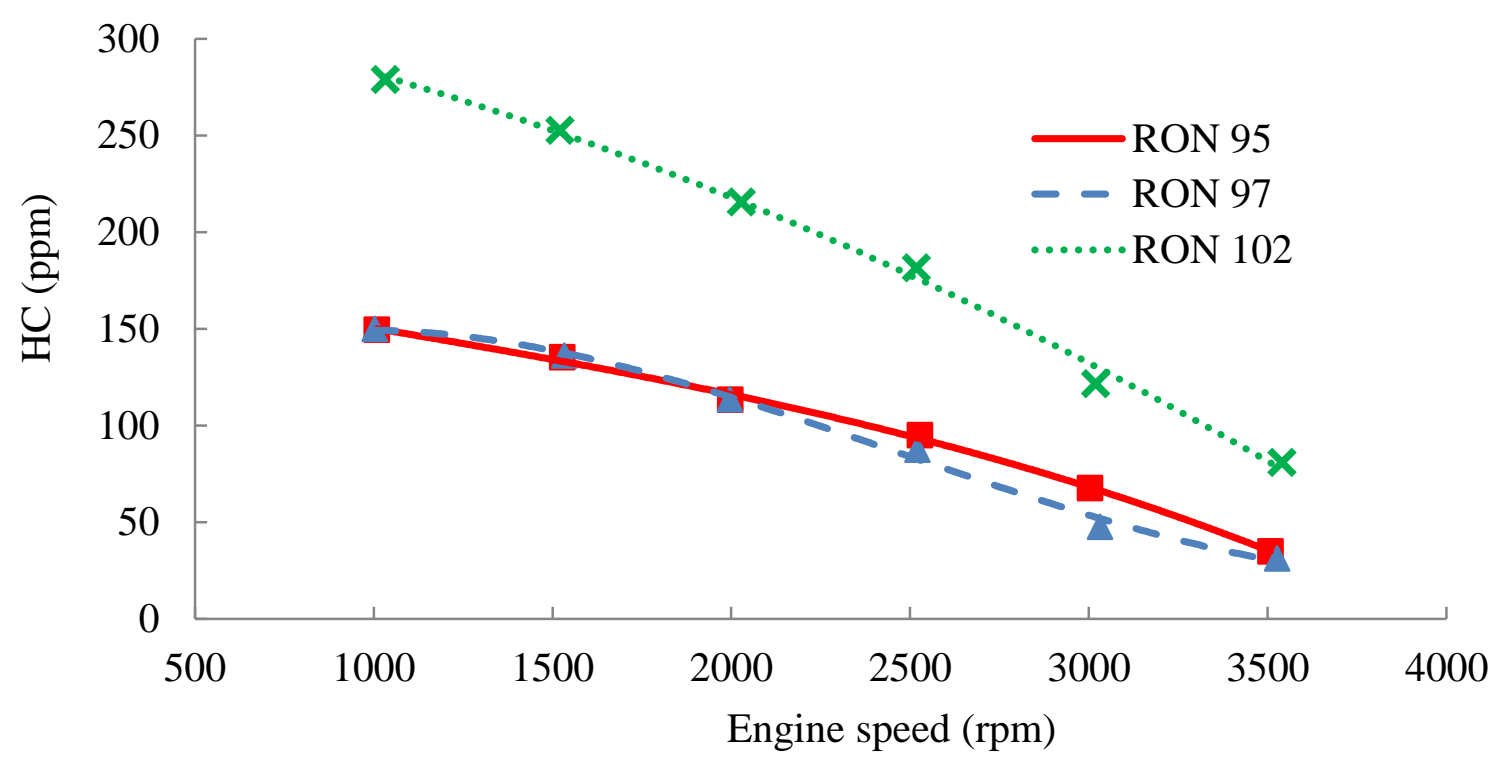

Figure 10. Variation of hydrocarbon emissions with engine speed.

Figure 10 shows the unburned $\mathrm{HC}$ emissions during the operation of the engine. In fact, the presence of $\mathrm{HC}$ in the exhaust gas was the result of unburnt or partially burnt fuels, incomplete combustion and the presence of lubricating engine oil in the fuel or combustion chamber [30]. For the HC constituent, the results indicated that the engine fuelled with RON102 generated higher emissions of HC gas than RON95 and RON97 in the ranges of $80-131 \%$ and $85-160 \%$, respectively. A high load produced more HC at a low speed. However, as the speed increased, the value was significantly reduced for all the fuels. The HC value of RON95 was found to be lower than that of RON102 fuel. This was attributed to the lower amount of tetra alkyl present in RON95 compared to RON102, although there was evidence of some deviation regarding the HC emissions of RON97 compared to RON95 at the speed of 2000 to $3500 \mathrm{rpm}$. This indicated the good ability of the engine to deliver a high volumetric efficiency. Therefore, the VVT system with the modification to the engine via the advance spark timing was suitable for RON97, according to the $\mathrm{HC}$ emission, but RON97 displayed a much higher reduction at higher speeds. The results showed that as the octane number increased, so did the $\mathrm{HC}$ emission, and the effectiveness of the octane number on the HC emission can be controlled by many other factors. In addition to previous causes, such as oxidation during the exhaust process and temperature distribution within the cylinder, there are other aspects that need to be considered to explain the detailed mechanism for the correlation of the octane number to the emission levels. It may also be related to the worn cylinder rings that caused the higher $\mathrm{HC}$ emissions with a high engine load [28]. This study found that an increase in the speed and reduction in the load reduced the $\mathrm{HC}$ emission. In previous studies [9], it was stated that by increasing the engine speed, the volumetric efficiency was improved and a more homogeneous mixture was promoted in the combustion chamber. Thus, the observed decrease in the $\mathrm{HC}$ emissions agreed with the results of the $\mathrm{HC}$ emissions for all three kinds of RON, which produced the lowest value at high engine speed. It was seen that the gasoline with the higher octane rating increased the concentration of $\mathrm{HC}$ and $\mathrm{CO}$ because the ratio of the tetra alkyl was enhanced by the higher RON than the engine design parameters. 


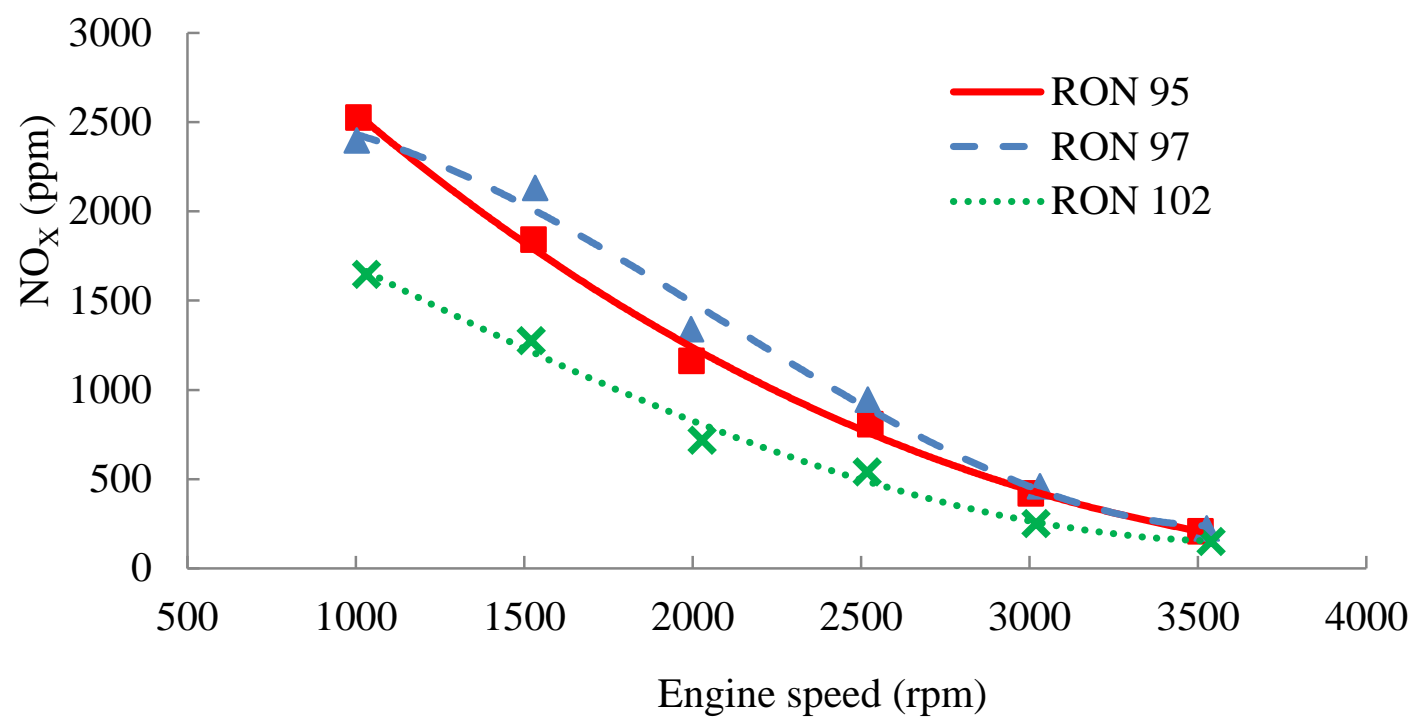

Figure 11. Effect of nitrogen oxide emissions gainst engine speed.

The emission of $\mathrm{NO}_{\mathrm{x}}$ from RON95, RON97 and RON102 gasolines is shown in Figure 11. The rate of $\mathrm{NO}_{\mathrm{x}}$ formation was found to be directly dependent on the cylinder temperature. The amount of $\mathrm{NO}_{\mathrm{x}}$ generated was also sensitive to the location within the cylinder. It was determined to be highest around the spark plug vicinity, where the temperature and pressure were at a maximum [31]. The generation of $\mathrm{NO}_{\mathrm{X}}$ was lowest for RON102 fuel compared to RON95 and RON97 fuels, at an average of 34\% and 40\%, respectively. RON97 produced higher $\mathrm{NO}_{\mathrm{x}}$ emissions compared to RON95 fuel at an average of $7.7 \%$. This higher $\mathrm{NO}_{\mathrm{x}}$ emission from RON97 was found to be more apparent at a higher engine speed. The emissions were enhanced with an increase in the engine load. This was because the cylinder temperature increased with the load as a result of intensified combustion. The higher cylinder temperature in the RON97 operation was also predicted from the higher power and torque observed at a high load. This was considered as the major reason for the higher $\mathrm{NO}_{\mathrm{x}}$ emissions with RON97 than RON95. It was also observed that the $\mathrm{NO}_{\mathrm{x}}$ emissions with RON95 occurred at intermediate values of RON102 and RON97. A decrease in $\mathrm{NO}_{\mathrm{x}}$ emissions for RON102 was owing to the requirement for a longer combustion period to achieve higher combustion efficiency. However, the appearance of lower CO and hydrocarbon emissions from RON95 and RON97 than RON102 operations was related to their higher combustion efficiency. This was also confirmed by the higher NOx emissions of RON95 and RON97 than RON102. From a technical and economical perspective, it is evident that RON95 has more potential and is favourable for the Malaysian automobile sector. Conversely, RON97 is good for producing higher engine power and torque, more BTE, less BSFC and less HC emissions. These attributes make RON97 much more attractive than RON95.

\section{CONCLUSIONS}

The combustion characteristics of various octane ratings for the feasibility of energyefficient vehicles were inspected. The engine performance, fuel economy and exhaust emissions of RON95, RON97 and RON102 gasoline grade fuels were experimentally evaluated on a representative Malaysian engine model. An analysis of the experimental 
results under the same engine specifications and operations led to the following conclusions:

i) Higher RON will result in higher torque and brake power, with RON102 showing the highest torque and brake power in all conditions compared to RON97 and RON95 fuels.

ii) A positive improvement in the brake specific fuel consumption (BSFC) was observed when RON97 was used to reduce fuel consumption by an average of 5$10 \%$ compared to RON102 and RON95.

iii) The BTE was remarkably improved by $12 \%$ using the higher-octane rating fuels of RON102 and RON97 compared to RON95.

iv) The RON102 fuel reduced the $\mathrm{NO}_{\mathrm{X}}$ emission by $34 \%$ compared to RON95 and by $40 \%$ compared to RON97 fuels.

v) RON102 fuel produced the highest $\mathrm{HC}$ emission compared to RON97 and RON 95 fuels.

vi) The CO emission was found to be higher for RON102 fuel compared to RON97 and RON95 fuels.

For the current situation in Malaysia, in order to fulfil the EEV requirements, RON97 offers high performance and efficiency in all conditions from low speeds to high speeds. It is also environmentally friendly as far as the octane rating in terms of energy efficiency is concerned. It has been asserted that RON97 fuel has more prospects than the more common RON95 fuel for use in Malaysian engine models with the latest technology, such as VVT, VTEC, MIVEC and CPS systems, for producing higher engine power, fuel economy and overall emissions.

\section{ACKNOWLEDGEMENTS}

The author would like to thank Ministry of Education Malaysia for supporting the research with the grant FRGS/2/2013/TK01/UKM/02/1.

\section{REFERENCES}

[1] Ghanaati A, Mat Darus IZ, Muhamad Said MF, Andwari AM. A Mean Value Model for Estimation of Laminar and Turbulent Flame Speed in Spark-Ignition Engine. International Journal of Automotive and Mechanical Engineering. 2015;11:2224-34.

[2] Ministry of International Trade and Industry National automotive policy: MITI; 2014.

[3] Fontanesi S, Cicalese G, d'Adamo A, Cantore G. A methodology to improve knock tendency prediction in high performance engines. Energy Procedia. 2014;45:769-78.

[4] Abdullah NR, Shahruddin NS, Mamat R, Ihsan Mamat AM, Zulkifli A. Effects of Air Intake Pressure on the Engine Performance, Fuel Economy and Exhaust Emissions of A Small Gasoline Engine. Journal of Mechanical Engineering and Sciences. 2014;6:949-58.

[5] Nagai K, Seko T. Trends of motor fuel quality in Japan. JSAE review. 2000;21:457-62.

[6] Jost K. Spark-ignition engine trends. Automotive Engineering. 2002. 
[7] Babu AR, Amba Prasad Rao G, Hari Prasad T. Direct injection of water mist in an intake manifold spark ignition engine. International Journal of Automotive and Mechanical Engineering. 2015;12:2809-19.

[8] Sayin C, Kilicaslan I, Canakci M, Ozsezen N. An experimental study of the effect of octane number higher than engine requirement on the engine performance and emissions. Applied Thermal Engineering. 2005;25:1315-24.

[9] Sayin C. The impact of varying spark timing at different octane numbers on the performance and emission characteristics in a gasoline engine. Fuel. 2012;97:85661.

[10] Mohamad TI, How HG. Part-load performance and emissions of a spark ignition engine fueled with RON95 and RON97 gasoline: Technical viewpoint on Malaysia's fuel price debate. Energy Conversion and Management. 2014;88:92835.

[11] Jamil N, Yusoff AR, Mansor MH. Literature Review of Electromagnetic Actuator Force Generation for Dynamic Modal Testing Applications. Journal of Mechanical Engineering and Sciences. 2012;3:311-9.

[12] Yashwanth MS, Venugopal T, Ramesh A. Experimental and simulation studies to determine the effective octane number in an engine fuelled with ethanol and gasoline. International Journal of Automotive and Mechanical Engineering. 2014;10:2057.

[13] Kamil M, Rahman MM. Effect of Injection Hole Diameter on Operational Conditions of Common-Rail Fuel-Injection System for Port-Injection HydrogenFueled Engine. International Journal of Automotive and Mechanical Engineering. 2015;11:2383-95.

[14] Hasan MM, Rahman MM, Kadirgama K. A Review on Homogeneous Charge Compression Ignition Engine Performance Using Biodiesel-Diesel Blend as a Fuel. International Journal of Automotive and Mechanical Engineering. 2015;11:2199-211.

[15] Ubeidalah SK. Assessment of Gasoline Quality Marketed in Accra Metropolis, Ghana: University of Ghana; 2015.

[16] Hoepke B, Jannsen S, Kasseris E, Cheng WK. EGR effects on boosted SI engine operation and knock integral correlation. SAE International Journal of Engines. 2012;5:547-59.

[17] A. Aziz AR, Firmansyah, Shahzad R. Combustion Analysis of a CNG Direct Injection Spark Ignition Engine. International Journal of Automotive and Mechanical Engineering. 2010;2:157-70.

[18] Smajevic I. Experimental Study and Computational Modelling of Gas-Fired Pulse Combustion. International Journal of Automotive and Mechanical Engineering. 2010;1:1-12.

[19] Sayin C, Ertunc HM, Hosoz M, Kilicaslan I, Canakci M. Performance and exhaust emissions of a gasoline engine using artificial neural network. Applied Thermal Engineering. 2007;27:46-54.

[20] Bradley D, Head R. Engine autoignition: the relationship between octane numbers and autoignition delay times. Combustion and Flame. 2006;147:171-84.

[21] Celik MB. Experimental determination of suitable ethanol-gasoline blend rate at high compression ratio for gasoline engine. Applied Thermal Engineering. 2008;28:396-404.

[22] Liu S, Clemente ERC, Hu T, Wei Y. Study of spark ignition engine fueled with methanol/gasoline fuel blends. Applied Thermal Engineering. 2007;27:1904-10. 
[23] Pourkhesalian AM, Shamekhi AH, Salimi F. Alternative fuel and gasoline in an SI engine: A comparative study of performance and emissions characteristics. Fuel. 2010;89:1056-63.

[24] Merola SS, Valentino G, Tornatore C, Marchitto L. In-cylinder spectroscopic measurements of knocking combustion in a SI engine fuelled with butanolgasoline blend. Energy. 2013;62:150-61.

[25] Knop V, Loos M, Pera C, Jeuland N. A linear-by-mole blending rule for octane numbers of n-heptane/iso-octane/toluene mixtures. Fuel. 2014;115:666-73.

[26] Babu A, Rao GAP, Prasad TH. Direct injection of water mist in an intake manifold spark ignition engine. International Journal of Automotive and Mechanical Engineering. 2015;12:2809.

[27] Nik Rosli A, Nafis Syabil S, Mohd A, Mamat I, Aminuddin Z. Effects of Air Intake Pressure to the Engine Performance, Fuel Economy and Exhaust Emissions on a Small Gasoline Engine. Journal of Mechanical Engineering and Sciences. 2014;6:949-58.

[28] Heywood J. Internal combustion engine fundamentals: McGraw-Hill Education; 1988.

[29] Sayin C, Canakci M. Effects of injection timing on the engine performance and exhaust emissions of a dual-fuel diesel engine. Energy Conversion and Management. 2009;50:203-13.

[30] Li T, Wu D, Xu M. Thermodynamic analysis of EGR effects on the first and second law efficiencies of a boosted spark-ignited direct-injection gasoline engine. Energy Conversion and Management. 2013;70:130-8.

[31] Esterhuyse N, Yates A. A Study to Assess the Effect of Octane on Vehicle Emissions. SAE Technical Paper; 2002. 